Terror in the Mind of God 


\section{COMPARATIVE STUDIES IN RELIGION AND SOCIETY}

Mark Juergensmeyer, editor

I. Redemptive Encounters: Three Modern Styles in the Hindu Tradition, by Lawrence Babb

2. Saints and Virtues, edited by John Stratton Hawley

3. Utopias in Conflict: Religion and Nationalism in Modern India, by Ainslee T. Embree

4. Mama Lola: A Vodou Priestess in Brooklyn, by Karen McCarthy Brown

5. The New Cold War? Religious Nationalism Confronts the Secular State, by Mark Juergensmeyer

6. Pious Passion: The Emergence of Modern Fundamentalism in the United States and Iran, by Martin Riesebrodt, translated by Don Reneau

7. Devi: Goddess of India, edited by John Stratton Hawley and Donna Marie Wulff

8. Absent Lord: Ascetics and Kings in a Jain Ritual Culture, by Lawrence A. Babb

9. The Challenge of Fundamentalism: Political Islam and the New World Disorder, by Bassam Tibi

Io. Levelling Crowds: Ethno-nationalist Conflicts and Collective Violence in South Asia, by Stanley J. Tambiah

II. The Bridge Betrayed: Religion and Genocide in Bosnia, by Michael A. Sells

I 2. China's Catholics: Tragedy and Hope in an Emerging Civil Society, by Richard Madsen

I3. Terror in the Mind of God: The Global Rise of Religious Violence, by Mark Juergensmeyer

I4. Imagining Karma: Ethical Transformation in Amerindian, Buddhist, and Greek Rebirth, by Gananath Obeyesekere

15. A Culture of Conspiracy: Apocalyptic Visions in Contemporary America, by Michael Barkun

16. Global Rebellion: Religious Challenges to the Secular State, by Mark Juergensmeyer 


\section{Terror in the Mind of God}

The Global Rise of Religious Violence

Fourth Edition

Revised and Updated

\section{Mark Juergensmeyer}

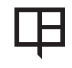

UNIVERSITY OF CALIFORNIA PRESS 
University of California Press, one of the most distinguished university presses in the United States, enriches lives around the world by advancing scholarship in the humanities, social sciences, and natural sciences. Its activities are supported by the UC Press Foundation and by philanthropic contributions from individuals and institutions. For more information, visit www.ucpress.edu.

University of California Press

Oakland, California

(C) 2017 by The Regents of the University of California

Library of Congress Cataloging-in-Publication Data

Names: Juergensmeyer, Mark, author.

Title: Terror in the mind of god : the global rise of religious violence / revised and updated Mark Juergensmeyer.

Other titles: Comparative studies in religion and society ; I3.

Description: Fourth edition. I Oakland, California : University of California Press, [2017] I Series: Comparative studies in religion and society ; I 3 I Includes bibliographical references and index.

Identifiers: LCCN 20I6040508 (print) I LCCN 20I6042080 (ebook) I ISBN 978052029I355 (pbk. : alk. paper) I ISBN 9780520965 I 64 ()

Subjects: LCSH: Violence-Religious aspects.

Classification: LCC BL65.V55 J84 2017 (print) I

LCC BL65.V55 (ebook) I DDC 205/.697-dc23

LC record available at https://lccn.loc.gov/20I 6040508

Manufactured in the United States of America

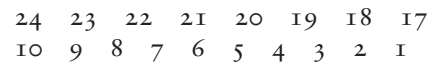


To terror's victims 

I will send my terror before you, and will throw into confusion all the people ...

-Exodus 23:27 
